\title{
Effects of Insulin-like Growth Factor-I on Glucose Tolerance, Insulin Levels, and Insulin Secretion
}

Peter D. Zenobi, Susanne Graf, Heinz Ursprung, and E. Rudolf Froesch

Division of Endocrinology and Metabolism, Department of Internal Medicine, University Hospital, Zurich, Switzerland

\begin{abstract}
Insulin-like growth factor-I (IGF-I) 1 and insulin interact with related receptors to lower plasma glucose and to exert mitogenic effects. Recombinant human IGF-I (rhIGF-I) was recently shown to decrease serum levels of insulin and C-peptide in fasted normal subjects without affecting plasma glucose levels. In this study we have investigated in six healthy volunteers the responses of glucose, insulin, and C-peptide levels to intravenous rhIGF-I infusions $(7$ and $14 \mu \mathrm{g} / \mathrm{kg} \cdot \mathrm{h}$ ) during standard oral glucose tolerance tests (oGTT) and meal tolerance tests (MTT), respectively.

Glucose tolerance remained unchanged during the rhIGF-I infusions in the face of lowered insulin and C-peptide levels. The decreased insulin/glucose-ratio presumably is caused by an enhanced tissue sensitivity to insulin. The lowered area under the insulin curve during oGTT and MTT as a result of the administration of rhIGF-I were related to the fasting insulin levels during saline infusion (oGTT: $r=0.825, P<0.05 ;$ MTT: $r=0.895, P<0.02)$. RhIGF-I, however, did not alter the ratio between $C$-peptide and insulin, suggesting that the metabolic clearance of endogenous insulin remained unchanged.

In conclusion, rhIGF-I increased glucose disposal and directly suppressed insulin secretion. RhIGF-I probably increased insulin sensitivity as a result of decreased insulin levels and suppressed growth hormone secretion. RhIGF-I, therefore, may be therapeutically useful in insulin resistance of type 2 diabetes, obesity, and hyperlipidemia. (J. Clin. Invest. 1992. 89:1908-1913.) Key words: insulin sensitivity • type 2 diabetes mellitus • insulin-like growth factor-II • glucose tolerance test • C-peptide
\end{abstract}

\section{Introduction}

Insulin-like growth factor-I (IGF-I) $)^{1}$ promotes growth and differentiation of cells and tissues (see reference 1 for review) and

This work has been presented in part at the 2nd International Symposium on IGF's, San Francisco, CA, 1991, and the 14th Meeting of the International Diabetes Federation, Washington, DC, 1991.

Address correspondence and reprint requests to Dr. Peter D. Zenobi, Division of Endocrinology and Metabolism, Department of Internal Medicine, University Hospital, Rämistrasse 100, 8091 Zurich, Switzerland.

Received for publication 5 August 1991 and in revised form 17 January 1992.

1. Abbreviations used in this paper: $\mathrm{AUC}$, areas under the curve; $\mathrm{CV}$, coefficients of variation; $\mathrm{GH}$, growth hormone; iAUC, incremental AUC; IGFBPs, insulin-like growth factor binding proteins; IGF-I, insulin-like growth factor-I; MTT, meal tolerance test; oGTT, oral glucose tolerance test; rhIGF-I, recombinant human IGF-I.

J. Clin. Invest.

(c) The American Society for Clinical Investigation, Inc.

$0021-9738 / 92 / 06 / 1908 / 06 \$ 2.00$

Volume 89, June 1992, 1908-1913 mimics several effects of insulin such as the stimulation of glucose transport and glycogen synthesis in muscle (2-4). While these effects are mostly mediated by the interaction of IGF-I with the type 1 IGF receptor on muscle cells (2-4), other important targets of insulin such as adipose tissue $(5,6)$ and liver cells (7) reveal few, if any, type 1 IGF receptors. Here, IGF-I interacts predominantly with insulin receptors $(6,7)$.

Recombinant human IGF-I (rhIGF-I), administered in high doses as intravenous bolus or infusion, caused hypoglycemia in animals (8-11) and in healthy humans (12). The hypoglycemic potency of rhIGF-I was about 12 -fold lower than that of insulin $(11,12)$. RhIGF-I increased glucose uptake of the skeletal muscle in vivo $(10,11,13)$, but was less effective in relation to insulin in the suppression of hepatic glucose production $(10,11,13,14)$. Furthermore, rhIGF-I exerts marked anabolic effects in hypophysectomized (15) and in diabetic rats (16). In fasting human subjects, infusions of rhIGF-I lowered insulin and C-peptide levels (17) as a result of the hypoglycemic effect $(4,11,12)$ and/or the suppression of insulin secretion via type 1 IGF receptors on the $\beta$-cells (18). RhIGF-I may also increase insulin sensitivity of target tissues through the decrease of glucose and consequently insulin levels and the suppression of growth hormone $(\mathrm{GH})$ secretion $(10,14,17)$.

Insulin resistance is characteristically found in acromegalic patients $(19,20)$ who have impaired glucose tolerance or frank diabetes in the face of hyperinsulinemia $(19,20)$. Prolonged fasting, on the other hand, is accompanied by low insulin levels (21-24) and impaired glucose tolerance (21-24) because of a delayed insulin response to hyperglycemia (21).

RhIGF-I administration has been shown to lower insulin and C-peptide levels in fasted subjects (17). Here, the effects of rhIGF-I infusions on glucose and meal tolerance and $\beta$ cell function were investigated, and we have found that glucose and meal tolerance were unaffected by rhIGF-I infusions while insulin and C-peptide levels decreased markedly and dose-dependently.

\section{Methods}

Subjects. Six healthy male volunteers $(24 \pm 2.5$ yr [mean \pm SD], range $21-28 \mathrm{yr}$, body mass index $22.6 \pm 1.9 \mathrm{~kg} / \mathrm{m}^{2}$ [mean $\pm \mathrm{SD}$ ], range $20.3-$ $25.6 \mathrm{~kg} / \mathrm{m}^{2}$ ) participated in the study after having given informed and written consent. Their weights remained constant for over $4 \mathrm{wk}$ before the study period. There was no family or personal history of diabetes or evidence of illness. Routine hematology and blood chemistry were within normal limits. The volunteers did not take drugs or alcohol during the 2 wk before and during the study. They consumed at least $250 \mathrm{~g}$ carbohydrates per day and abstained from excessive exercise during $3 \mathrm{~d}$ before each part of the study. The protocol was approved by the Ethics Committee of the Department of Medicine of the University Hospital of Zurich.

Experimental protocol. The study consisted of three periods of $2 \mathrm{~d}$ each during which the volunteers received infusions of 7 and $14 \mu \mathrm{g}$ rhIGF-I/ $\mathrm{kg}$ body wt per $\mathrm{h}$ i.v., and saline in a randomized crossover fashion. The volunteers were blinded to the type of infusion they were receiving. The three study periods were at least $10 \mathrm{~d}$ apart. 
During each part of the study, the volunteers received a sucrose-free diet of $2,400 \mathrm{kcal} / \mathrm{d}$, composed of $50 \%$ carbohydrates, $30 \%$ fat, and $20 \%$ protein which were given as breakfast at 8 a.m. ( $500 \mathrm{kcal})$, lunch at 1 p.m. ( $950 \mathrm{kcal})$, and dinner at 7 p.m. $(950 \mathrm{kcal})$. No snacks were allowed between meals.

For each part of the study, the volunteers arrived at the metabolic unit at 7 a.m. of day 1 after an overnight fast. Before 7.30 a.m., an 18 Gauge Venflon ${ }^{\oplus}$ cannula was inserted in an antecubital vein of the left forearm and connected to a portable miniaturized infusion pump (MRS-3®; Disetronic AG, Burgdorf, Switzerland) with a cartridge containing saline or rhIGF-I (kindly supplied by Ciba-Geigy AG, Basel, Switzerland). RhIGF-I, dissolved in saline $(10 \mathrm{mg} / \mathrm{ml})$, or saline was infused starting at 8 a.m. of day 1 until 5 p.m. of day 2 . The volunteers were discharged from the metabolic research unit on the following day (day 3).

On day 1 , blood was sampled before 8 a.m. from the Venflon ${ }^{\oplus}$ on the left and at $6 \mathrm{p} . \mathrm{m}$. from a venepuncture site on the right arm. After breakfast at 8 a.m. of day 1, capillary plasma glucose levels were measured every $2 \mathrm{~h}$ until $10 \mathrm{p}$.m. to ascertain that no hypoglycemia occurred.

After a 12-h overnight fast, breakfast was substituted by a standard oral glucose tolerance test (oGTT) with $75 \mathrm{~g}$ glucose at $8 \mathrm{a}$.m. of day 2 . To draw blood in regular intervals, an 18-gauge Abbocath ${ }^{\oplus}$ cannula was inserted in an antecubital vein of the right $\mathrm{arm} 30 \mathrm{~min}$ before the oGTT and connected to an infusion of $0.9 \%$ saline to keep it patent.

At 1 p.m. of the same day (day 2) meal tolerance tests (MTT) were performed. Lunch, consisting of $115 \mathrm{~g}$ carbohydrates, was eaten within less than 30 min. Blood was drawn from the Abbocath ${ }^{\bullet}$ cannula at regular intervals until 5 p.m., as indicated in the Figures.

Methods. Blood was drawn into tubes containing sodiumfluoride oxalate, centrifuged within $10 \mathrm{~min}$, and analyzed immediately for glucose. Venous blood was drawn into tubes (SST ${ }^{\oplus}$; Becton Dickinson, Meylan Cedex, France) for separation of serum. After clot retraction for $30 \mathrm{~min}$ at $4^{\circ} \mathrm{C}$ and centrifugation at $1,550 \mathrm{~g}$ for $30 \mathrm{~min}$ at $4^{\circ} \mathrm{C}$, aliquots of serum were stored at $-20^{\circ} \mathrm{C}$ until assayed for serum levels of insulin, C-peptide, GH, total IGF-I and IGF-II, and "free" IGF-I.

Plasma glucose was determined on a glucose analyzer (Model 2; Beckman Instruments, Inc., Fullerton, CA). Insulin, C-peptide, and GH were determined using commercially available RIAs (Medipro AG, Teufen, Switzerland). All samples from individual volunteers were analyzed within one assay in duplicates or triplicates at one or two dilutions. The interassay coefficients of variation (CV) were 12.4 and $8.5 \%$ for insulin ( 180 and $680 \mathrm{pmol} / \mathrm{liter}$ ), 5.8 and $2.1 \%$ for C-peptide ( 280 and $1400 \mathrm{pmol} / \mathrm{liter}$ ), and $0.65 \%$ for GH ( $320 \mathrm{nmol} / \mathrm{liter}$ ).

For the analysis of total IGF-I and IGF-II, $250 \mu \mathrm{l}$ serum were extracted through Sep-Pak $\mathrm{C}_{18}$ (Waters Associates, Milford, MA) according to the protocol supplied by the manufacturer to dissociate IGF from the insulin-like growth factor binding proteins (IGFBPs). The eluate was dried under a stream of air at $37^{\circ} \mathrm{C}$, lyophilized, and dissolved in PBS containing 0.2\% HSA for the assays of IGF-I and IGF-II in duplicates at three or four dilutions.

IGF-I was analyzed by the method of Zapf et al. (25) which was modified. The first incubation was omitted and $0.1 \mathrm{ml}$ of the sample or rhIGF-I standard, $0.2 \mathrm{ml}$ IGF-I antiserum diluted at 1:1,000, and 0.1 $\mathrm{ml}{ }^{125}$ I-IGF-I were simultaneously added. The samples were incubated for $24 \mathrm{~h}$ at $4^{\circ} \mathrm{C}$, and antibody-bound ${ }^{125}$ I-IGF-I was precipitated with $40 \mu \mathrm{g}$ of rabbit gamma globulin and $50 \mu \mathrm{l}$ of goat anti-rabbit gamma globulin, diluted 1:4 with PBS/0.2\% HSA. Within a range from 17 to $130 \mathrm{nmol}$ IGF-I/liter, the results obtained were indistinguishable from those obtained with the originally reported method (mean difference $\pm \mathrm{SD}-0.9 \pm 2.6 \%$, range -6.8 to $+8.5 \%$ ). The inter- and intraassay $\mathrm{CV}$ for the modified method were 5.0 and $2.8 \%$, respectively, and those for the original method 5.2 and $2.2 \%$, respectively. The $K_{d}$ with the modified method was $30.9 \mathrm{nmol} /$ liter, compared with $11.4 \mathrm{nmol} /$ liter with the original method.

The RIA for total IGF-II was carried out as described (25). RhIGFII was used as standard. The inter- and intraassay CV were 9.1 and $6.7 \%$, respectively.

Free IGF-I was separated from IGF bound to IGFBPs by chromatography on a Sephadex G-50 fine column $(0.75 \times 29 \mathrm{~cm}$, bed volume $14.5 \mathrm{ml}$, flow rate $2 \mathrm{ml} / \mathrm{h}$ ), equilibrated with $0.15 \mathrm{M} \mathrm{NH}_{4} \mathrm{HCO}_{3} / 0.02 \%$ $\mathrm{NaN}_{3} / 0.02 \%$ HSA (pH 7.8). Free ${ }^{125}$ I-IGF-I eluted between 40 and $77 \%$ bed volume. By analysis with Western ligand blotting (26) we observed no detectable IGFBPs in the range between 52 and $77 \%$ bed volume with up to 15-fold higher amounts of eluate than routinely loaded on a lane (not shown). 100- $\mu$ l serum samples were, therefore, gel filtrated, and fractions between 52 and $77 \%$ bed volume were pooled, lyophilized, dissolved in $1 \mathrm{ml}$ distilled water, and relyophilized. The material was dissolved in $225 \mu \mathrm{l}$ PBS for analysis of IGF-I by RIA in duplicates, as described (8).

Statistics. The results of this study in a small number of subjects ( $n$ = 6) cannot be expected to be normally distributed. Thus, Friedman's rank variance analysis (two tailed) for the overall comparison, and Wilcoxon's matched pairs signed rank test (two tailed) for the pairwise comparison of the results were used $(27,28)$. Areas under the curve (AUC) and linear regressions were calculated using the trapezoidal rule and the method of least squares, respectively. A $P$ value of less than 0.05 was considered significant.

\section{Results}

Serum levels of total IGF-I and IGF-II, and free IGF-I were normal before the start of the infusions, and they remained unaltered during the control infusions with $0.9 \%$ saline (Table

Table I. Mean \pm SD of Total IGF-I, Free IGF-I, and Total IGF-II Levels during Intravenous Infusion of rhIGF-I or Saline

\begin{tabular}{|c|c|c|c|c|c|c|c|c|c|}
\hline \multirow[b]{2}{*}{ Infusion } & \multicolumn{3}{|c|}{ Total IGF-I (nmol/liter) } & \multicolumn{3}{|c|}{ Free IGF-I (nmol/liter) } & \multicolumn{3}{|c|}{ Total IGF-II (nmol/liter) } \\
\hline & Saline & $\begin{array}{c}7 \mu \mathrm{g} \text { rhIGF-I } \\
\text { per } \mathrm{kg} \cdot \mathrm{h}\end{array}$ & $\begin{array}{l}14 \mu \mathrm{g} \text { rhlGF-I } \\
\text { per } \mathrm{kg} \cdot \mathrm{h}\end{array}$ & Saline & $\begin{array}{c}7 \mu \mathrm{g} \text { rhIGF-I } \\
\text { per } \mathrm{kg} \cdot \mathrm{h}\end{array}$ & $\begin{array}{c}14 \mu \mathrm{g} \text { rhIGF-I } \\
\text { per } \mathrm{kg} \cdot \mathrm{h}\end{array}$ & Saline & $\begin{array}{c}7 \mu \mathrm{g} \text { rhIGF-I } \\
\text { per } \mathrm{kg} \cdot \mathrm{h}\end{array}$ & $\begin{array}{c}14 \mu \mathrm{g} \text { rhIGF-I } \\
\text { per } \mathrm{kg} \cdot \mathrm{h}\end{array}$ \\
\hline \multicolumn{10}{|l|}{ Day 1} \\
\hline 8 a.m. & $24 \pm 3$ & $25 \pm 3$ & $27 \pm 7$ & $1.2 \pm 1.1$ & $1.3 \pm 1.0$ & $1.4 \pm 0.5$ & $70 \pm 10$ & $70 \pm 7$ & $79 \pm 21$ \\
\hline 6 p.m. & $23 \pm 4^{*}$ & $75 \pm 11^{11 * *}$ & $111 \pm 26^{11 * *}$ & $1.0 \pm 0.4^{\S}$ & $3.3 \pm 2.7^{* *}$ & $18.9 \pm 17.9^{1 * *}$ & $73 \pm 8$ & $54 \pm 5^{1 * *}$ & $60 \pm 18^{* *}$ \\
\hline 8 a.m. & $24 \pm 4^{*}$ & $93 \pm 17^{\| 1 \pm}$ & $120 \pm 28^{11 * *}$ & $1.3 \pm 1.1^{\S}$ & $2.8 \pm 2.8^{* *}$ & $7.2 \pm 5.4^{1 * *}$ & $69 \pm 9 \ddagger$ & $35 \pm 7^{1 \neq \pm}$ & $25 \pm 10^{\prime \neq t}$ \\
\hline 12 a.m. & $23 \pm 4^{\ddagger}$ & $97 \pm 15^{1 \ddagger \pm}$ & $120 \pm 25^{7 * *}$ & $1.5 \pm 1.0^{\ddagger}$ & $2.4 \pm 1.2^{* *}$ & $6.9 \pm 4.0^{1 * *}$ & $72 \pm 10^{*}$ & $32 \pm 9^{11 \neq}$ & $23 \pm 6^{11 \neq}$ \\
\hline 5 p.m. & $24 \pm 4^{\ddagger}$ & $99 \pm 16^{1 \pm \pm}$ & $125 \pm 28^{1 * *}$ & $1.3 \pm 1.0^{\ddagger}$ & $2.4 \pm 0.9^{* *}$ & $8.1 \pm 7.0^{1 * *}$ & $71 \pm 7^{*}$ & $31 \pm 8^{11 \ddagger \pm}$ & $22 \pm 7^{11}$ \\
\hline
\end{tabular}

${ }^{*} P<0.001{ }^{\ddagger} P<0.01$, and ${ }^{5} P<0.05$ by overall comparison between the three different infusions at the same time (Friedman). " and $P<0.05$ by pairwise comparison (Wilcoxon) vs. the two other types of infusion and vs. saline infusion at the same time, respectively. $* * P<0.05$ vs. day 1,8 a.m., $P<0.05$ vs. day 1,8 a.m. and 6 p.m. of the same infusion type by pairwise comparison (Wilcoxon). 
I). In response to the rhIGF-I infusions total and free IGF-I levels were raised within $10 \mathrm{~h}$ after the start of the infusions, whereas total IGF-II was decreased. On day 2, IGF-I levels were 3.9 and 4.4 times (total), and 1.8 and 4.1 times (free), respectively, above starting levels during the infusions of 7 and $14 \mu \mathrm{g}$ rhIGF-I $/ \mathrm{kg} \cdot \mathrm{h}$, respectively, whereas total IGF-II levels decreased as expected (17) to 50 and $32 \%$, respectively. These IGF levels were reached before the start of the oGTT. Furthermore, GH levels on day 2 were decreased during the infusions of 7 and $14 \mu \mathrm{g}$ rhIGF-I/ $\mathrm{kg} \cdot \mathrm{h}$ compared with control infusions (Table II).

Plasma glucose levels on day 1 ranged between 3.1 and 5.6 $\mathrm{mmol} /$ liter (not shown) and were, like the glucose profiles on day 2 (Fig. 1, top), not affected by the administration of rhIGFI. The glycemic peak responses and the AUC for glucose $\left(\mathrm{AUC}_{\text {glucose }}\right)$ between 8 and 10 a.m. during oGTT were slightly delayed and increased during the rhIGF-I infusions $(P>0.05)$. When the $\mathrm{AUC}_{\text {glucose }}$ was calculated for the periods between 8 a.m. and 1 p.m. during oGTT and that between 1 and 5 p.m. during MTT, they were indistinguishable whether or not rhIGF-I was infused $(21 \pm 2$ and $21 \pm 2 \mathrm{mmol} / \mathrm{liter} \cdot \mathrm{h}$ during saline, $21 \pm 3$ and $21 \pm 2 \mathrm{mmol} / \mathrm{liter} \cdot \mathrm{h}$ during $7 \mu \mathrm{g} \mathrm{rhIGF-I/} \mathrm{kg} \cdot \mathrm{h}$, and $23 \pm 3$ and $21 \pm 2 \mathrm{mmol} / \mathrm{liter} \cdot \mathrm{h}$ during $14 \mu \mathrm{g} \mathrm{rhIGF}-\mathrm{I} / \mathrm{kg} \cdot \mathrm{h}$, respectively).

Serum levels of insulin and C-peptide were lowered in a dose-dependent fashion already $10 \mathrm{~h}$ after the start of the rhIGF-I infusions $(P<0.05$, not shown), and also on day 2 , in the fasting state as well as during oGTT and MTT (Fig. 1, middle and bottom). The $\mathrm{AUC}_{\text {insulin }}$ and $\mathrm{AUC}_{\mathrm{C} \text {-peptide }}$ decreased proportionately and similarly during oGTT and MTT (Table III). As suggested by the decrease of the incremental AUC (iAUC) $)_{\text {insulin }}$ and iAUC $_{\text {C-peptide }}$ during the rhIGF-I infusions (not shown), the decrease of the AUCs cannot solely be explained by decreased fasting insulin and $\mathrm{C}$-peptide levels. The decrease of the $\mathrm{AUC}_{\text {insulin }}$ and $\mathrm{iAUC}_{\text {insulin }}$, respectively, during rhIGF-I infusions indicates that less insulin is required to dispose of a glucose load during the infusion of rhIGF-I.

The insulin levels during oGTT and MTT decreased in the volunteers during the infusion of $14 \mu \mathrm{g}$ rhIGF-I $/ \mathrm{kg} \cdot \mathrm{h}$ as a function of fasting insulin levels during saline infusion (Fig. 2). The relation was similar with the infusion of $7 \mu \mathrm{g} \mathrm{rhIGF-I/kg} \cdot \mathrm{h}(r$ $=0.825, P<0.05$ during $O$ GTT and $r=0.895, P<0.02$ during MTT). The findings indicate that insulin levels are decreased more markedly by rhIGF-I infusions in subjects with high normal than in those with low normal fasting insulin levels.

The insulin/glucose-ratio which can be considered as an

Table II. Growth Hormone Levels during Intravenous Infusion of rhIGF-I or Saline

\begin{tabular}{lccc}
\hline & \multicolumn{3}{c}{ Mean \pm SD of growth hormone } \\
\cline { 2 - 4 } Infusion & Saline & $\begin{array}{c}7 \mu g \text { rhIGF-I } \\
\text { per } \mathrm{kg} \cdot \mathrm{h}\end{array}$ & $\begin{array}{c}14 \mu \mathrm{\mu g} \text { rhIGF-I } \\
\text { per } \mathrm{kg} \cdot \mathrm{h}\end{array}$ \\
\hline & & $n g / \mathrm{ml}$ & \\
& & $<0.20^{*}$ & $0.21 \pm 0.02$ \\
8 a.m. & $0.41 \pm 0.34$ & $0.65 \pm 1.0$ & $0.20 \pm 0.01$ \\
1 p.m. & $2.26 \pm 2.62$ & $0.20 \pm 0.01$ & $0.24 \pm 0.06$ \\
\hline p.m. & $0.23 \pm 0.03$ & & \\
\hline
\end{tabular}

* Several growth hormone levels were below the detection limit of the assay and were mathematically treated as equal to $0.2 \mathrm{ng} / \mathrm{ml}$.
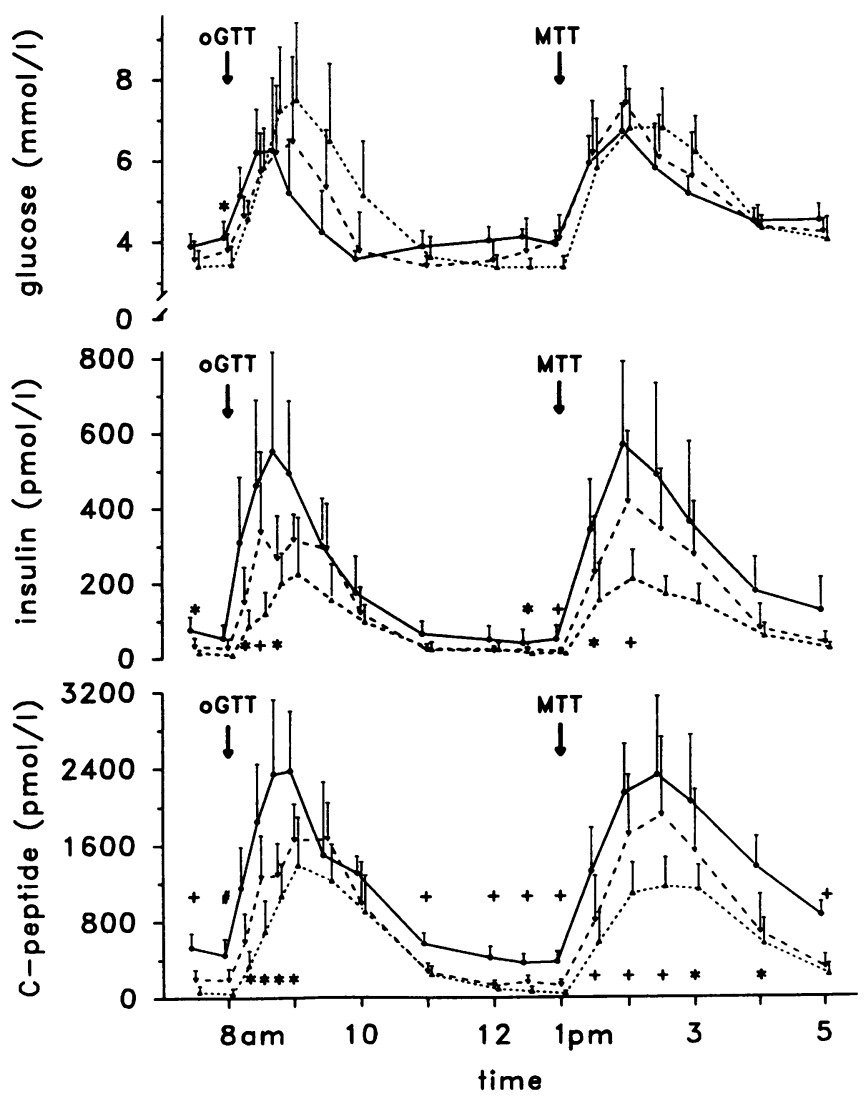

Figure 1. Glucose, insulin, and C-peptide levels during infusion of saline or rhIGF-I. Plasma glucose, insulin, and C-peptide levels during intravenous infusion of saline $(-), 7 \mu \mathrm{g}$ of rhIGF-I/ $\mathrm{kg} \cdot \mathrm{h}(---)$, and $14 \mu \mathrm{g}$ of $\mathrm{rhIGF}-\mathrm{I} / \mathrm{kg} \cdot \mathrm{h}(--.--)$ in six healthy volunteers during oGTT at 8 a.m. and MTT at 1 p.m. Mean + SD are given. ${ }^{*} P<0.05$, ${ }^{+} P<0.01,{ }^{"} P=0.001$ by Friedman analysis. The pairwise analysis (Wilcoxon) revealed that plasma glucose levels were significantly lower at 11 a.m., 1.30 p.m. ( $7 \mu$ rhIGF-I $/ \mathrm{kg} \cdot \mathrm{h}$ vs. saline), 8 a.m., and between $12 \mathrm{a} . \mathrm{m}$. and $1 \mathrm{p} . \mathrm{m}$. (14 $\mu \mathrm{g}$ rhIGF-I $/ \mathrm{kg} \cdot \mathrm{h}$ vs. saline). The insulin levels were significantly decreased between 7.30 and 8.45 a.m., between $12.30 \mathrm{a} . \mathrm{m}$. and $2 \mathrm{p} . \mathrm{m}$. (14 $\mu \mathrm{g}$ rhIGF-I/ $\mathrm{kg} \cdot \mathrm{h}$ vs. saline), at 8.30, 9.30 a.m., 2.30 and 3 p.m. (14 vs. $7 \mu$ ghIGF-I/kg $\cdot h$ h), 1 and 2 p.m. ( $7 \mu \mathrm{g}$ rhIGF-I $/ \mathrm{kg} \cdot \mathrm{h}$ vs. saline). C-peptide levels were significantly lower between 7.30 and 9, 11 and 12.30 a.m., 1 and 2, 3 and 5 p.m.

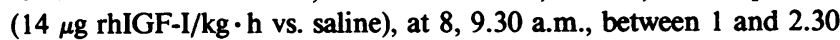

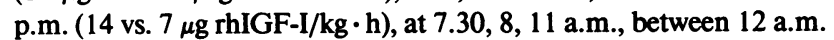
and $1.30 \mathrm{p} . \mathrm{m}$., and at $5 \mathrm{p} . \mathrm{m}$. ( $7 \mu \mathrm{g}$ rhIGF-I/kg $\cdot \mathrm{h}$ vs. saline).

index of tissue sensitivity to insulin (29) was decreased in response to rhIGF-I infusions at all time points, both before and during oGTT and MTT, respectively (Fig. 3). The pairwise analysis revealed significantly decreased ratios at $10(14 \mu \mathrm{g}$ rhIGF-I/kg $\cdot \mathrm{h}$ vs. saline), $3(14 \mu \mathrm{g}$ rhIGF-I/kg $\cdot \mathrm{h}$ vs. $7 \mu \mathrm{g}$ rhIGF-I/kg $\cdot \mathrm{h})$, and $2(7 \mu \mathrm{g} \mathrm{rhIGF}-\mathrm{I} / \mathrm{kg} \cdot \mathrm{h}$ vs. saline) time points. In contrast, the C-peptide/insulin-ratio was not affected by rhIGF-I infusions before oGTT and MTT (Fig. 4). It may be assumed, therefore, that the metabolic clearance of insulin remained unchanged.

\section{Discussion}

IGF-I mimics many effects of insulin such as stimulating glucose transport in muscle and fat cells and glycogen synthesis in 
Table III. Area under the Insulin and C-Peptide Curve during Intravenous Infusion of rhIGF-I or Saline

\begin{tabular}{|c|c|c|c|}
\hline Infusion & Saline & $\begin{array}{c}7 \mu \mathrm{g} \text { rhIGF-I } \\
\text { per } \mathrm{kg} \cdot \mathrm{h}\end{array}$ & $\begin{array}{l}14 \mu \mathrm{g} \mathrm{rhIGF}- \\
\text { per } \mathrm{kg} \cdot \mathrm{h}\end{array}$ \\
\hline \multicolumn{4}{|c|}{ oGTT (8 a.m. to 1 p.m.) } \\
\hline $\mathrm{AUC}_{\text {Insulin }}{ }^{*}$ & $935 \pm 265^{\ddagger}$ & $600 \pm 180$ & $385 \pm 175^{8}$ \\
\hline $\mathrm{AUC}_{\mathrm{C} \text {-peptide }}{ }^{*}$ & $5320 \pm 600^{\ddagger}$ & $3640 \pm 600^{\S}$ & $2770 \pm 585^{\S}$ \\
\hline \multicolumn{4}{|c|}{ MTT (1 to 5 p.m.) } \\
\hline $\mathrm{AUC}_{\text {Insulin }}$ & $1230 \pm 475^{\ddagger}$ & $800 \pm 360$ & $450 \pm 145^{\S}$ \\
\hline $\mathrm{AUC}_{\mathrm{C} \text {-peptide }}$ & $6360 \pm 1485^{\ddagger}$ & $4250 \pm 1600$ & $2990 \pm 755^{5}$ \\
\hline
\end{tabular}

* Mean $\pm S D$ of the area under the insulin curve $\left(\mathrm{AUC}_{\mathrm{insulin}}\right)$ and the area under the $\mathrm{C}$-peptide curve $\left(\mathrm{AUC}_{\mathrm{C} \text {-peptide }}\right)$ in pmol/liter $\cdot \mathrm{h}$ during OGTT and MTT. ${ }^{\ddagger} P<0.01$ by overall comparison (Friedman), ${ }^{8} P$ $<0.05$ vs. saline, " $P<0.05$ vs. $7 \mu \mathrm{g}$ rhIGF-I by pairwise comparison (Wilcoxon).

muscle in vitro (2-6) as well as in vivo (8-14). RhIGF-I administered as an intravenous bolus into animals $(8,9)$ and humans (12) raised free IGF-I levels and caused hypoglycemia. When compared on a molar basis, the hypoglycemic potency of rhIGF-I is about 12-fold lower than that of insulin $(11,12)$, while, in vitro, IGF-I is slightly less potent than insulin on

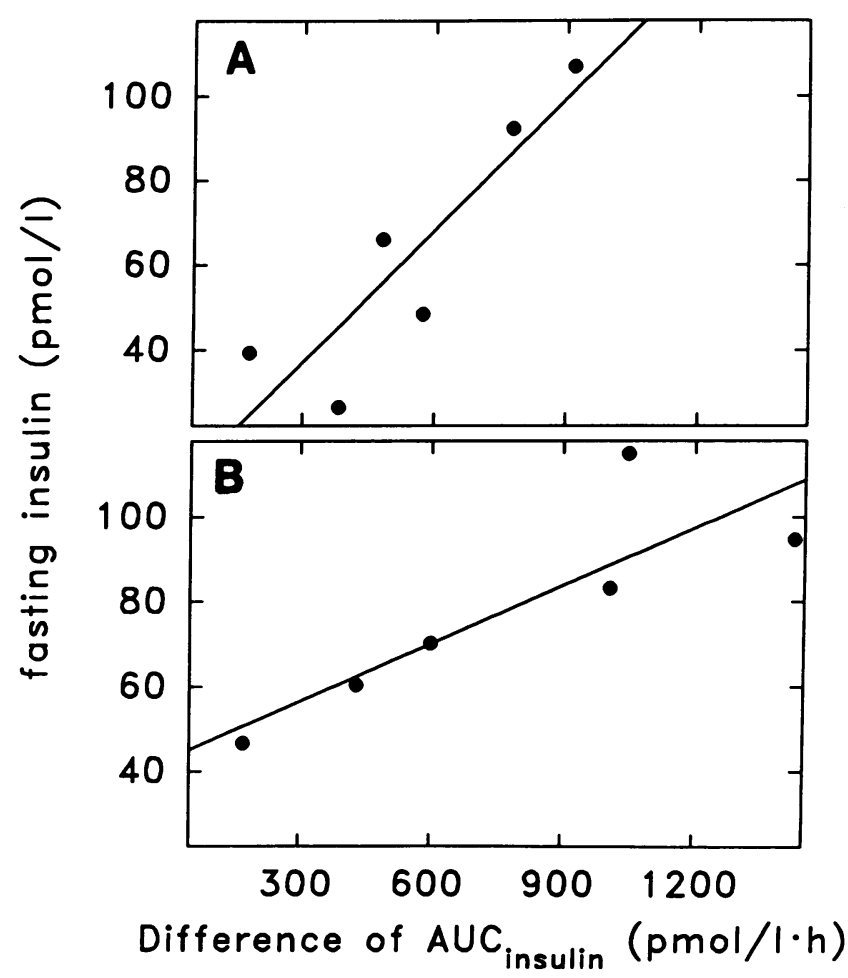

Figure 2. Insulin levels versus difference of the area under the insulin curve. The areas under the insulin curve $\left(\mathrm{AUC}_{\text {insulin }}\right)$ during oGTT and MTT were calculated as well as the differences between the AU$\mathrm{C}_{\text {insulin }}$ during the infusion of saline minus that during the infusion of $14 \mu \mathrm{g}$ rhIGF-I/ $\mathrm{kg} \cdot \mathrm{h}$. The fasting insulin levels during saline infusion are plotted vs. these differences of the $\mathrm{AUC}_{\text {insulin }}$ during $0 \mathrm{GTT}$ $(A ; y=0.1 \times+5.8, r=0.887, P<0.03)$ and MTT $(B ; y=0.046$ $X+43, r=0.854, P<0.035)$. Each circle represents the value of one volunteer.

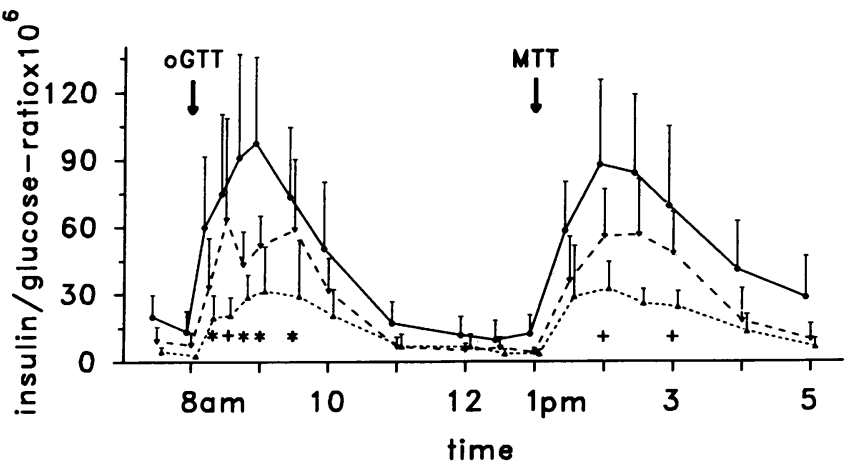

Figure 3. Insulin/glucose-ratio during infusion of rhIGF-I. Insulin/ glucose-ratio $\times 10^{6}$ during intravenous infusion of saline $(-), 7 \mu \mathrm{g}$ of rhIGF-I $/ \mathrm{kg} \cdot \mathrm{h}(---)$, and $14 \mu \mathrm{g}$ of rhIGF-I/ $\mathrm{kg} \cdot \mathrm{h}(----)$ in six healthy volunteers during $O G T T$ at $8 \mathrm{a} . \mathrm{m}$. and MTT at $1 \mathrm{p} . \mathrm{m}$. Mean $+\mathrm{SD}$ are given. ${ }^{*} P<0.05,{ }^{+} P<0.01$ by Friedman analysis.

muscle cells $(2,3)$, and far less effective on liver $(10,11)$ and adipose cells $(5,6)$. This difference is explained by the high density of type 1 IGF receptors on muscle cells (2-4) and their low density or absence on liver and adipose cells (5-7). Apparently, the effects of IGF-I are mediated through interaction with the type 1 IGF receptor on muscle cells and cross reaction with insulin receptors on adipocytes and hepatocytes.

In this and earlier studies in humans and animals IGF-I infusions increased total IGF-I levels two- to fivefold $(10,11$, 17). Under basal conditions, most of the circulating IGF-I is bound to specific IGFBPs (30) that prevent IGF-I from causing hypoglycemia (8). When exogenously administered rhIGF-I exceeded the binding capacity of the IGFBPs, serum levels of free IGF-I levels were increased $(17,30)$. In our study, free IGF-I levels were even more increased $10 \mathrm{~h}$ after starting the rhIGF-I infusion than later on (Table I), since IGFBPs increase with some delay (26). Therefore, we assume that the free IGF-I levels caused insulin-like effects that resulted in an unaltered glucose tolerance in the face of markedly decreased insulin and C-peptide levels (Fig. 1).

However, high total IGF-I levels do not always mimic the effects of insulin. Total IGF-I levels are raised into the range of the present study in acromegalic patients who are insulin resis-

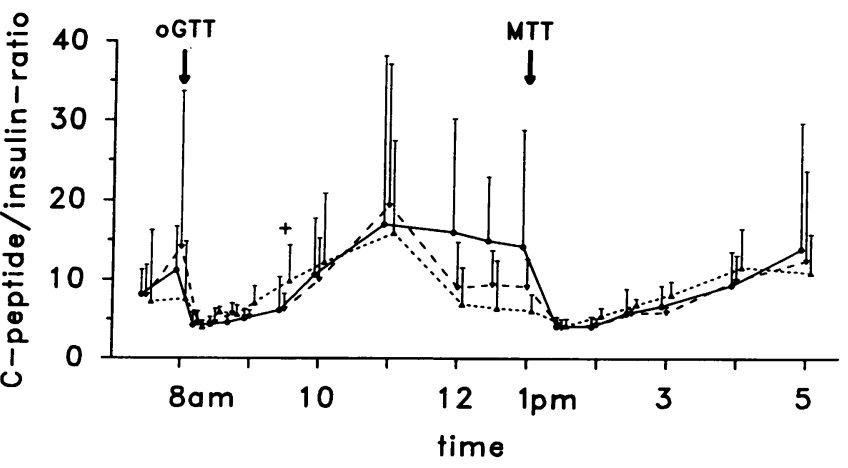

Figure 4. C-peptide/insulin-ratio during infusion of rhIGF-I. C-peptide/insulin-ratio during intravenous infusion of saline $(-), 7 \mu \mathrm{g}$

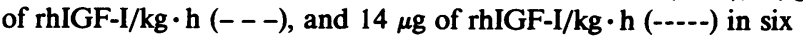
healthy volunteers during $0 \mathrm{GTT}$ at $8 \mathrm{a} . \mathrm{m}$. and MTT at 1 p.m. Mean $+\mathrm{SD}$ are given. ${ }^{+} P=0.01$ by Friedman analysis. 
tant, as indicated by glucose intolerance and concomitantly elevated insulin and C-peptide levels $(19,20)$. Furthermore, increased GH levels induce IGFBP-3 and the acid-labile subunit of the IGFBP-3 complex (26, 31-34), which provide for a high IGF-binding capacity (34) and cause increased insulin levels $(19,20)$ that suppress IGFBP-1 and -2 production (33). IGF-I in acromegaly is, therefore, mostly bound to the IGFBP3 complex which is linked to anabolic and growth effects (1). In contrast, rhIGF-I infusions are known to suppress GH secretion (Table II, reference 17) and to increase serum levels of IGFBP-1 and -2 (26) as a result of the concomitant insulin deficiency and subsequently enhanced hepatic expression of IGFBP-1 and -2 (35-38). While IGFBP-3 levels are virtually unchanged during rhIGF-I infusions (26), serum levels of IGFBP-1 and -2 with short half lives are increased and carry proportionally larger amounts of total IGF-I (30). Thus, during rhIGF-I infusions glucose disposal in peripheral tissues is likely to be increased due to elevated serum levels of free IGF-I and increased levels of IGFBP-1 and -2 that cross the vascular barrier into the interstitial space, as shown in the rat heart (39), and from which IGF-I may dissociate. This may have resulted in slightly, though not significantly lower fasting and preprandial glucose levels and a direct and indirect inhibition of insulin and C-peptide secretion $(40,41)$. Furthermore, rising insulin levels during oGTT diminish IGFBP-1 levels $(36,37)$ so that more free IGF-I may dissociate during oGTT and MTT and stimulate glucose disposal further $(36,38)$, as suggested by the decreased iAUC $_{\text {insulin }}$ during oGTT and MTT during rhIGF-I administration. These mechanisms explain in part the unchanged glucose tolerance despite decreased insulin levels.

Insulin resistance associated with hyperinsulinemia of type 2 diabetes and obesity $(22,23,42,43)$ is improved by diet and weight loss through the decrease of insulin levels (42-44). Thus, the improved tissue sensitivity to insulin during rhIGF-I infusions may also be due to decreased insulin levels. However, very low insulin levels as a result of prolonged fasting (21-24) are accompanied by increased GH (22), a delayed insulin response (21), and impaired glucose tolerance, i.e., "starvationdiabetes" $(21,22)$. In this study, we have noted during oGTT that rhIGF-I infusions slightly retarded insulin and C-peptide responses (Fig. 1), but the discrete changes did not impair glucose tolerance during the $33 \mathrm{~h}$ of the rhIGF-I infusions. Prolonged infusions of higher amounts of rhIGF-I, however, may be diabetogenic. Indeed, an infusion of $16 \mu \mathrm{g} \mathrm{rhIGF}-\mathrm{I} / \mathrm{kg} \cdot \mathrm{h}$ in a child with Laron-type dwarfism caused fasting hypoglycemia and, at the same time, glucose intolerance due to the suppression of insulin secretion (45), whereas the administration of smaller amounts of rhIGF-I for $7 \mathrm{~d}$ to healthy volunteers did not cause glucose intolerance (46). RhIGF-I administration for $5 \mathrm{~d}$ to type 2 diabetics on a weight-maintaining diet even improved glucose tolerance (47). Here, the insulin/glucose-ratio remained decreased throughout the rhIGF-I infusions (Fig. 3), indicating that tissue sensitivity to insulin remained unaltered.

The suppression of insulin secretion by rhIGF-I has been demonstrated in isolated pancreatic $\beta$-cells (40), in the perfused rat pancreas (41), as well as in vivo in this study in normal human subjects (Fig. 1). It may by itself result in an increased tissue sensitivity to insulin (42-44), an interpretation which is supported by a close relation between fasting insulin levels and the difference between the $\mathrm{AUC}_{\text {insulin }}$ during the infusion of saline and that during rhIGF-I (Fig. 2). It implies that rhIGF-I has a more pronounced effect in subjects with high normal than in those with low normal insulin levels.

In conclusion, rhIGF-I administered to healthy men decreased insulin and C-peptide levels but did not change glucose tolerance. RhIGF-I, therefore, improves glucose disposal and may also increase tissue sensitivity to insulin because of decreased insulin levels and suppressed GH secretion. Glucose tolerance may also be maintained despite decreased insulin levels as a result of elevated levels of free IGF-I dissociating from the IGFBPs during oGTT and MTT. Independent of the mechanism of action, rhIGF-I may become an important therapeutic principle in states associated with insulin resistance such as obesity, type 2 diabetes, severe insulin resistance, and hyperlipidemia.

\section{Acknowledgments}

We thank Dr. S. Jaeggi, Mrs. Y. Glatz, and Mrs. M. Waldvogel for the technical assistance, Mrs. M. Salman for secretarial help, and Dr. J. A. Fischer for critical review of the manuscript.

This work has been supported by the Swiss National Science Foundation (grant 31-9095.87) and by Ciba-Geigy AG, Basel.

\section{References}

1. Froesch, E. R., H. P. Guler, Chr. Schmid, M. Ernst, P. D. Zenobi, and J. Zapf. 1989. Growth promotion by insulin-like growth factor I: endocrine and autocrine regulation. In Auxology 88. Perspectives in the Science of Growth and Development. J. M. Tanner, editor. Smith-Gordon, London. 251-263.

2. Poggi, C., Y. Le Marchand-Brustel, J. Zapf, E. R. Froesch, and P. Freychet. 1979. Effects and binding of insulin-like growth factor in the isolated soleus muscle of lean and obese mice: comparison with insulin. Endocrinology. 195:723-730.

3. Yu, K. T., and M. P. Czech. 1984. The type I insulin-like growth factor receptor mediates the rapid effects of multiplication-stimulating activity on membrane transport systems in rat soleus muscle. J. Biol. Chem. 259:3090-3095.

4. Dohm, G. L., C. W. Elton, M. S. Raju, N. D. Mooney, R. DiMarchi, W. J. Pories, E. G. Flickinger, S. M. Atkinson, and J. F. Caro. 1990. IGF-I-stimulated glucose transport in human skeletal muscle and IGF-I resistance in obesity and NIDDM. Diabetes. 30:1028-1032.

5. King, G. L., C. R. Kahn, M. M. Rechler, and S. P. Nissley. 1980. Direct demonstration of separate receptors for growth and metabolic activities of insulin and multiplication-stimulating activity (an insulin-like growth factor) using antibodies to the insulin receptor. J. Clin. Invest. 66:130-140.

6. Sinha, M. K., C. Buchanan, N. Leggett, L. Martin, P. G. Khazanie, R. DiMarchi, W. J. Pories, and J. F. Caro. 1989. Mechanism of IGF-I-stimulated glucose transport in human adipocytes. Demonstration of specific IGF-I receptors not involved in stimulation of glucose transport. Diabetes. 38:1217-1225.

7. Caro, J. F., J. Poulos, O. Ittoop, W. J. Pories, E. G. Flickinger, and M. K. Sinha. 1988. Insulin-like growth factor I binding in hepatocytes from human liver, human hepatoma, and normal, regenerating, and fetal liver. J. Clin. Invest. 81:976-981.

8. Zapf, J., C. Hauri, M. Waldvogel, and E. R. Froesch. 1986. Acute metabolic effects and half-lives of intravenously administered insulinlike growth factors I and II in normal and hypophysectomized rats. J. Clin. Invest. 77:1768-1775.

9. Zenobi, P. D., H. P. Guler, J. Zapf, and E. R. Froesch. 1988. Insulin-like growth factors in the Gottinger miniature-pig. Acta Endocrinol. 117:343-352.

10. Jacob, R., E. Barrett, G. Plewe, K. D. Fagin, and R. S. Sherwin. 1989. Acute effects of insulin-like growth factor I on glucose and amino acid metabolism in the awake fasted rat. Comparison with insulin. J. Clin. Invest. 83:17171723.

11. Giacca, A., R. Gupta, S. Efendic, K. Hall, A. Skottner, L. Lickley, and M. Vranic. 1990. Differential effects of IGF-I and insulin on glucoregulation and fat metabolism in depancreatized dogs. Diabetes. 39:340-347.

12. Guler, H. P., J. Zapf, and E. R. Froesch. 1987. Short-term metabolic effects of recombinant human insulin-like growth factor $I$ in healthy adults. $N$. Engl. J. Med. 317:137-140.

13. Rossetti, L., S. Frontoni, R. Dimarchi, R. A. DeFronzo, and A. Giaccari. 1991. Metabolic effects of IGF-I in diabetic rats. Diabetes. 40:444-448.

14. Jacob, R. J., R. S. Sherwin, L. Bowen, D. Fryburg, K. D. Fagin, W. V. Tamborlane, and G. I. Shulman. 1991. Metabolic effects of IGF.I and insulin in spontaneously diabetic BB/w rats. Am. J. Physiol. 260:E262-268. 
15. Schoenle, E., J. Zapf, R. E. Humbel, and E. R. Froesch. 1982. Insulin-like growth factor I stimulates growth in hypophysectomized rats. Nature (Lond.). 296:252-253.

16. Scheiwiller, E., H. P. Guler, J. Merryweather, C. Scandella, J. Maerki, J. Zapf, and E. R. Froesch. 1986. Growth restoration of insulin-deficient diabetic rats by recombinant human insulin-like growth factor I. Nature (Lond.). 323:169-171.

17. Guler, H. P., C. Schmid, J. Zapf, and E. R. Froesch. 1989. Effects of recombinant insulin-like growth factor $I$ on insulin secretion and renal function in normal human subjects. Proc. Natl. Acad. Sci. USA. 86:2868-2872.

18. Van Schravendijk, C. F. H., A. Foriers, J. L. Van den Brande, and D. G. Pipeleers. 1987. Evidence for the presence of type I insulin-like growth factor receptors on rat pancreatic A and B cells. Endocrinology. 121:1784-1788.

19. Sönksen, P. H., F. C. Greenwood, J. P. Ellis, C. Lowy, A. Rutherford, and J. D. N. Nabarro. 1967. Changes of carbohydrate tolerance in acromegaly with progress of the disease and in response to treatment. J. Clin. Endocrinol. Metab. 27:1418-1430.

20. Luft, R., E. Cerasi, and C. A. Hamberger. 1967. Studies on the pathogenesis of diabetes in acromegaly. Acta Endocrinol. 56:593-607.

21. Unger, R. H., A. M. Eisentraut, and L. L. Madison. 1963. The effects of total starvation upon the levels of circulating glucagon and insulin in man. $J$. Clin. Invest. 42:1031-1039.

22. Cahill, G. F. M. G. Herrera, A. P. Morgan, J. S. Soeldner, J. Steinke, P. L. Levy, G. A. Reichard, and D. M. Kipnis. 1966. Hormone-fuel interrelationships during fasting. J. Clin. Invest. 45:1751-1769.

23. DeFronzo, R. A., V. Soman, F. S. Sherwin, R. Hendler, and P. Felig. 1978 Insulin binding to monocytes and insulin action in human obesity, starvation, and refeeding. J. Clin. Invest. 62:204-213.

24. Newman, W. P., and R. G. Brodows. 1983. Insulin action during acute starvation: evidence for selective insulin resistance in normal man. Metab. Clin. Exp. 32:590-596.

25. Zapf, J., H. Walter, and E. R. Froesch. 1981. Radioimmunological determination of insulinlike growth factors I and II in normal subjects and in patients with growth disorders and extrapancreatic tumor hypoglycemia. J. Clin. Invest. 68:1321-1330.

26. Zapf, J., Ch. Schmid, H. P. Guler, M. Waldvogel, Ch. Hauri, E. Futo, P. Hossenlopp, M. Binoux, and E. R. Froesch. 1990. Regulation of binding proteins for insulin-like growth factors (IGF) in humans. J. Clin. Invest. 86:952-961.

27. Bland, M. 1989. An Introduction to Medical Statistics. Oxford Medical Publications. Oxford University Press. 216-240.

28. Ciba-Geigy, AG, Basel. 1985. Wissenschaftliche Tabellen Geigy, Teilband Statistik. 8th edition, Basel. 9-233.

29. Feek, C. M., J. S. Bevan, S. Taylor, N. S. Brown, and J. D. Baird. 1981. The effect of bromocriptine on insulin secretion and glucose tolerance in patients with acromegaly. Clin. Endocrinol. 15:473-478.

30. Guler, H. P., J. Zapf, Ch. Schmid, and E. R. Froesch. 1989. Insulin-like growth factors I and II in healthy man. Estimations of half-lives and production rates. Acta Endocrinol. 121:753-758.

31. Copeland, K. C., L. E. Underwood, and J. J. Van Wyk. 1980. Induction of immunoreactive somatomedin $\mathrm{C}$ in human serum by growth hormone: Dose-response relationships and effect on chromatographic profiles. J. Clin. Endocrinol. Metab. 50:690-697.

32. Baxter, R. C., and J. L. Martin. 1986. Radioimmunoassay of growth hormone dependent insulin-like growth factor binding protein in human plasma. J. Clin. Invest. 78:1504-1512.

33. Hardouin, S., M. Gourmelen, P. Noguiez, D. Seurin, M. Roghani, Y. Le Bouc, G. Povoa, T. J. Merimee, P. Hossenlopp, and M. Binoux. 1989. Molecular forms of serum insulin-like growth factor (IGF)-binding proteins in man: Relationships with growth hormone and IGFs and physiological significance. J. Clin. Endocrinol. Metab. 69:1291-1301.

34. White, R. M., S. P. Nissley, A. C. Moses, M. M. Rechler, and R. E. Johnsonbaugh. 1981. The growth hormone dependence of a somatomedin-binding protein in human serum. J. Clin. Endocrinol. Metab. 53:49-57.

35. Suikkari, A. M., V. A. Koivisto, E. M. Rutanen, H. Yki-Järvinen, S. L. Karonen, and M. Seppälä. 1988. Insulin regulates the serum levels of low molecular weight insulin-like growth factor-binding protein. J. Clin. Endocrinol. Metab. 66:266-272.

36. Yeoh, S. E., and R. C. Baxter. 1988. Metabolic regulation of the growth hormone independent insulin-like growth factor binding protein in human plasma. Acta Endocrinol. 119:465-473.

37. Suikkari, A. M., V. A. Koivisto, R. Koistinen, M. Seppälä, and H. YkiJärvinen. 1989. Dose-response characteristics for suppression of low molecular weight plasma insulin-like growth factor-binding protein by insulin. J. Clin. Endocrinol. Metab. 68:135-140.

38. Snyder, D. K., and D. R. Clemmons. 1990. Insulin-dependent regulation of insulin-like growth factor-binding protein-1. J. Clin. Endocrinol. Metab. 71:1632-1636.

39. Bar, R. S., D. R. Clemmons, M. Boes, W. H. Busby, B. A. Booth, B. L. Dake, and A. Sandra. 1990. Transcapillary permeability and subendothelial distribution of endothelial and amniotic fluid insulin-like growth factor binding proteins in the rat heart. Endocrinology. 127:1078-1086.

40. Van Schravendijk, C. F. H., L. Heylen, J. L. Van den Brande, and D. G. Pipeleers. 1990. Direct effect of insulin and insulin-like growth factor-I on the secretory activity of rat pancreatic beta cells. Diabetologia. 33:649-653.

41. Leahy, J. L., and K. M. Vandekerkhove. 1990. Insulin-like growth factor-I at physiological concentrations is a potent inhibitor of insulin secretion. Endocrinology. 126:1593-1598.

42. Archer, J. A., P. Gorden, and J. Roth. 1975. Defect in insulin binding to receptors in obese man. Amelioration with caloric restriction. J. Clin. Invest. 55:166-174.

43. Bar, R. S., L. C. Harrison, M. Muggeo, P. Gorden, C. R. Kahn, and J. Roth. 1979. Regulation of insulin receptors in normal and abnormal physiology in humans. Adv. Intern. Med. 24:23-52.

44. Henry, R. R., P. Wallace, and J. M. Olefsky. 1986. Effects of weight loss on mechanisms of hyperglycemia in obese non-insulin-dependent diabetes mellitus. Diabetes. 35:990-998.

45. Walker, J. L. M. Ginalska-Malinowska, T. E. Romer, J. B. Pucilowska, and L. E. Underwood. 1991. Effects of the infusion of insulin-like growth factor in a child with growth hormone insensitivity syndrome (Laron dwarfism). $N$. Engl. J. Med. 324:1483-1488.

46. Takano, K., N. Hizuka, K. Shizume, K. Asakawa, I. Fukuda, and $H$. Demura. 1991. Repeated sc administration of recombinant human insulin-like growth factor I (IGF-I) to human subjects for 7 days. Growth Regul. 1:23-28.

47. Zenobi, P. D., S. Graf, S. Jäggi, and E. R. Froesch. 1991. Metabolic effects of recombinant human insulin-like growth factor-I (rhIGF-I) in non-insulin dependent type II diabetes mellitus. Abstracts of the 73rd Annual Meeting of the Endocrine Society, Washington DC: 226a. (Abstr.) 